Artículo Original. The effect of life kinetic training on learning of shot put glide technique and motoric parameters. Vol. 7, n. ${ }^{\circ}$ 3; p. 363-385, septiembre 2021. https://doi.org/10.17979/sportis.2021.7.3.7445

\title{
The effect of life kinetic training on learning of shot put glide technique and motoric parameters
}

\section{El efecto del entrenamiento cinético de vida en el aprendizaje de la técnica de tiro-put glide y parámetros motóricos}

Özlem Orhan, Ebru Çetin, Sezen Çimen Polat, İmdat Yarım

Gazi University Sport Sciences Faculty, 06330,Ankara, Turkey.

Corresponding Author: Özlem Orhan, Gazi University Sport Sciences Faculty, Emniyet mah. 1.Cad, 10/1D 06500 Yenimahalle, Ankara,Turkey, e-mail oarslan@gazi.edu.tr, Phone: +90 312 2023557, Fax:+90 3122122274

Cronograma editorial: Artículo recibido21/01/2021 Aceptado: 01/06/2021 Publicado: 01/09/2021

https://doi.org/10.17979/sportis.2021.7.3.7445

Para citar este artículo utilice la siguiente referencia: Orhan, O.; Cetin, E.; Cimen, Polat S.; Yarim, I. (2021). The effect of life kinetic training on learning of shot put glide technique and motoric parameters. Sportis Sci J, 7 (3), 344-362. https://doi.org/10.17979/sportis.2021.7.3.7445

Contribución específica de los autores: Ö.O., E.Ç., S.Ç.P., İ.Y. han contribuido al diseño e implementación de la investigación, al análisis de los resultados y a la redacción del manuscrito.

Financiación: No existió financiación para esta investigación.

Consentimiento informado participantes del estudio: Se informó a los participantes sobre la naturaleza del estudio y también se les informó que la participación era voluntaria y que podían retirarse en cualquier momento.

Conflicto de interés: Los autores declaran no tener conflicto de interés relacionado con este estudio. 
Artículo Original. The effect of life kinetic training on learning of shot put glide technique and motoric parameters. Vol. 7, n. ${ }^{\circ}$ 3; p. 363-385, septiembre 2021. https://doi.org/10.17979/sportis.2021.7.3.7445

\begin{abstract}
This study determined the effect of life kinetic (LK) training on the learning of glide techniques, shot performance and motor parameters of students in the faculty of sports sciences. A total of 54 students, 24 females (19.2 2 .1years) and 30 males (19.6 \pm 1.9 years), who were studying in faculty of sports sciences participated in the research. Students participated in the track and field lesson twice a week for 12 weeks. The experimental group was made to exercise LK training for 30 minutes before each lesson after the general warmup. Before and after the 12-weeks of training, measurements were taken from students two times. Willcoxon T-test was applied in order to determine whether or not there were differences between the pre-test and post-test which were applied before and after the training program. Mann Whitney $U$ test was used in order to determine whether or not there was a difference between the two groups. Statistical significance level was taken as $\mathrm{p}<0.05 \mathrm{As}$ a result of the research, statistically significant differences were determined between the experimental and control group in the shot put distance, glide technique, agility, visual reaction, auditory reaction parameters. In brief, it may be stated that LK training positively affected the development of skills and technical learning of students.
\end{abstract}

\title{
Keywords
}

Life kinetic training; shot put throw learning; motor parameters; track and field; glide technique

\section{Resumen}

Este estudio determinó el efecto del entrenamiento cinético de la vida (LK) sobre el aprendizaje de técnicas de deslizamiento, rendimiento de tiro y parámetros motores de estudiantes de la facultad de ciencias del deporte. Participaron de la investigación 54 estudiantes, 24 mujeres $(19,2 \pm 2,1$ años) y 30 hombres $(19,6 \pm 1,9$ años), que cursaban estudios en la facultad de ciencias del deporte. Los estudiantes participaron en la lección de pista y campo dos veces por semana durante 12 semanas. Se hizo que el grupo experimental ejercitara el entrenamiento LK durante 30 minutos antes de cada lección después del calentamiento general. Antes y después de las 12 semanas de formación, se tomaron medidas de los estudiantes dos veces. Se aplicó la prueba $\mathrm{T}$ de Willcoxon para determinar si existían diferencias entre la prueba previa y la prueba posterior que se aplicaron antes y después del programa de entrenamiento. Se utilizó la prueba U de Mann Whitney para determinar si había o no una diferencia entre los dos grupos. El nivel de significancia estadística se tomó como $\mathrm{p}$ $<0.05$ Como resultado de la investigación, se determinaron diferencias estadísticamente significativas entre el grupo experimental y control en la distancia de lanzamiento de bala, técnica de planeo, agilidad, reacción visual, parámetros de reacción auditiva. En resumen, se puede afirmar que la formación LK afectó positivamente el desarrollo de habilidades y el aprendizaje técnico de los estudiantes.

\section{Palabras clave}

Entrenamiento cinético vital; aprendizaje de lanzamiento de peso; parámetros motores; pista y campo; técnica de planeo. 

parameters. Vol. 7, n. ${ }^{\circ} 3$; p. 363-385, septiembre 2021. https://doi.org/10.17979/sportis.2021.7.3.7445

\section{Introduction}

LK training was based on findings that were obtained as a result of extensive researches on neurology that follow the motor and kinematic methods. It is a training model which includes exercises that provide constant active thinking (Duda, 2015). This method drew the attention of sports scientists and started to be used as an entertaining and instructive practice (Yarım, Cetin \& Orhan, 2019). In LK training, individuals exercise with simultaneous exercises that are combined with visual and cognitive elements (Lutz, 2014). LK training contain to concentrate on different visual and physical tasks (Komarudin \& Awwaludin, 2018). As a result of this, the training improves neuromuscular coordination by establishing new neural connections or strengthening the existent connections in the neural system (Hannes, 2009). The combination of this training apply with exercises of various difficulties that differ according to the skill levels of individuals. As the difficulty levels increase, the exercises become more difficult in order to affect the development of the brain and neurological system more (Duda, 2015; Lutz, 2010). When the conducted researches are examined, it can be clearly observed that LK exercises influence the cognitive process (Lutz, 2014; Duda, 2015; Komarudin \& Awwaludin, 2018). Athletes can possess coordinative skills that are trained well with LK training (Stern, 2002). When the use of LK exercise in sportive branches is examined, it is frequently investigated whether or not these exercises contribute to the learning and development of technique (Duncan, Eyre \& Oxford, 2018). Technique means performing the basic motions of a sportive branch in the most economical way and fit for purpose and it is extremely important in all of the branches of sports (Lees, 2002). In the learning of technique, the brain which is an active element is obliged to develop new connections in order to correspond to this condition (Duncan, Eyre \& Oxford, 2018).

The technique is crucial for a good performance in track\&field and it even includes contents that constitute the basis for all of the sports branches. Jumping, throwing, walking and running which constitute the branch of track\&field are motions that are used in the natural life of humans and include the basic skills. Strength and technical competence are extremely important for a good performance in the throwing branches of track\&field (Meron \& Saint-Phard, 2017). Special training is required in order to provide the development of each 
Artículo Original. The effect of life kinetic training on learning of shot put glide technique and motoric parameters. Vol. 7, n. ${ }^{\circ}$ 3; p. 363-385, septiembre 2021. https://doi.org/10.17979/sportis.2021.7.3.7445

stage of motion phases (Caleb et al., 2017). Shot put which is one of the throwing branches of track\&field and used in this research is a branch which requires high power generation (Zaras et al., 2013). The technique for the shot put consists of the standing throw followed by the more technical skill with the acceleration of the body and implement by either the glide or rotation method followed by the "power" position and release (Mike et al., 2014). Glide technique requires an explosive power along with the correct technique that would be performed in a limited area (Linthorne, 2001). Maximum velocity and neuromuscular activation are extremely important as well as the muscular strength for a good performance (Kyriazis, Terzis, Boudolos \& Georgiadis, 2009).

The number of neurons and the development of the brain show the quality of a brain, not its size (Goriely, Budday \& Kuh, 2015). It is possible to increase this development with LK training (Komarudin \& Awwaludin, 2018). They can become successful athletes who can comprehend the motion quickly, take quick decisions and reflect these skills to their performances (Stern, 2002). In the conducted researches, elite athletes and teams from different branches stated that they felt the effects of LK exercises and LK exercises positively affected their coordinative skills (Lutz, 2017) and it was observed that these exercises had positive effects on reaction time and learning which directly affect the sportive performance but did not have any effect on the balance skill (Vural, 2016). When the literature is examined, it can be observed that this training is commonly used on football players and it is known that several professional football teams create a special squad for these exercises. When the literature is surveyed in terms of LK training, it was observed that there was a limited amount of research on sportive branches (Duda, 2015; Komarudin \& Awwaludin, 2018; Vural, 2016). As a result of the examinations, it is considered that LK training could be beneficial for technical learning and motor skills based on its effects on learning and cognitive process. The aim of the research was to determine the effect of LK training on the learning of glide techniques, shot performance and motor parameters of male and female university students in the faculty of sports sciences

\section{Materials and methods}


Artículo Original. The effect of life kinetic training on learning of shot put glide technique and motoric parameters. Vol. 7, n. ${ }^{\circ}$ 3; p. 363-385, septiembre 2021. https://doi.org/10.17979/sportis.2021.7.3.7445

Participants: A total of 54 students, 24 females (19.2 \pm 2.1 years) and 30 males (19.6 \pm 1.9 years), who were studying in faculty of sports sciences participated in the research. All students who took athletics lessons and volunteered during the semester were included in the study. The subjects were randomly separated into two as experimental $(n=26)$ and control $(n=28)$ group. Height, body weight and BMI values of experimental group were determined as (pre: $174.4 \pm 2.29 \mathrm{~cm}, 67.6 \pm 2.94 \mathrm{~kg}, 21.8 \pm 0.5 \mathrm{~kg} / \mathrm{m}^{2}$ - post: $174.4 \pm 2.23 \mathrm{~cm}, 67.3 \pm 2.79 \mathrm{~kg}$, $21.9 \pm 0.5 \mathrm{~kg} / \mathrm{m} 2)$. Participants were informed about the nature of the study and were also informed that participation was voluntary and that they could withdraw at any time.

Study design: The study was conducted in accordance with the Declaration of Helsinki and approved by the Ethics Committee of the Gazi University (Code: 77082 166-302.08.01 / 2018-248). In the study, the selection was made by paying attention to the fact that the students had never been trained in shot put technique. Before the measurements, the glide technique was taught to all of the students who participated in the research theoretically for 4 lessons $(4 \times 50$ min.) and it was tried to teach them with practice. Then, the students were separated randomly two groups. Both of the groups participated in the track\&field lesson twice a week for 12 weeks. The total duration of the athletics lesson is included in the program as 50 minutes. During the first 20 minutes of the course, all students were given both theoretically and practically information about the shot put technique. Then, the application phase is started in the lesson. Decathlon shot drills are applied for the first 10 minutes for warm up and also preparation technic education. At the last stage, 20 minutes of step-by-step technical training is applied.

The experimental group performed 30 minutes of LK training before the lessons. The control group was prepared for the lesson by doing standard warm-up exercises for 30 minutes before the lesson in athletics.

Measurements: Measurements were taken from students two times, before and after the 12-weeks of training. The assessments were carried out for two days in the athletic field of The Faculty of Sports Sciences at Gazi University. Weather was calm and sunny during all of the throwing and other evaluations.

Body weight, velocity and agility tests were conducted for two days and after 48 hours, shot put test was conducted. During the assessments, the values of height $(\mathrm{cm})$, body weight 

parameters. Vol. 7, n. ${ }^{\circ} 3$; p. 363-385, septiembre 2021. https://doi.org/10.17979/sportis.2021.7.3.7445

$(\mathrm{kg})$, Body Mass Index (BMI) $\left(\mathrm{kg} / \mathrm{m}^{2}\right)$, body fat percentage (\%), 20m velocity (sec), agility $(\mathrm{sec})$, shot put $(\mathrm{cm})$, glide technique (points), right and left visual and auditory reaction time (ms) were determined.

Body Fat Percentage and BMI: Weight and body fat percentage of the body and the torso were analysed by bioelectric impedance (Tanita BC 418: Arlington Heights, Il, USA).

Illinois Agility Test (IAT): The IAT performance was recorded using an electronic timing system (Microgate SARL, Bolzano, Italy). The test is set up with 4 cones that are used to mark the start and 2 turning points, whereas another 4 cones were placed down towards the start line at equal $3.3 \mathrm{~m}$ distance apart. The cone's height was $30 \mathrm{~cm}$. The subject would sprint $10 \mathrm{~m}$, turn and return back to the start line, and then they would swerve in and out of 4 markers, completing the test with two 10-m sprints in the opposite direction. The players were instructed not to shortcut the markers, but to run around them. If a subject failed to do this, the trial was stopped and repeated after the standard recovery period (Amiri-Khorasani, Sahebozamani, Tabrizi \& Yusof, 2010).

Sprint Testing: Linear sprinting was evaluated with $20 \mathrm{~m}$ using an electronic timing system (Microgate SARL). Participants started 0.3-m before the first infrared photoelectric gate, which was placed $0.75-\mathrm{m}$ above the ground to ensure the capturing of the trunk movement and avoid false signals through limb motion. The ICCs (Castel, Pratt \& Drummond, 2005) for test-retest trials was 0.96 , and 0.95 for $20 \mathrm{~m}$, respectively.

Reaction time: The simple reaction time was measured using an electronic timing system (Newtest 1000 device, Newtest Oy, Oulu, Finland) including a digital display, a light, and a button, and the protocol described by Lutz (2014) was followed. Each athlete was seated so that the resting arm was on the table in a quiet environment. The testing side's second index was placed one $\mathrm{cm}$ away from the button of the device. Then, the participants were asked to press the button when the visual or auditory input appeared. A total of ten repetitions were recorded, and the mean score of the last five tests was further analysed (Jain, Bansal, Kumar \& Singh, 2015). The visual and auditory reaction time was randomly assigned, and the throwing and non-throwing arms were tested separately. The reaction time was recorded with a sensitivity of $1 / 1000 \mathrm{~s}$. 
Artículo Original. The effect of life kinetic training on learning of shot put glide technique and motoric parameters. Vol. 7, n. ${ }^{\circ}$ 3; p. 363-385, septiembre 2021. https://doi.org/10.17979/sportis.2021.7.3.7445

Shot put: All of the subjects shot with the shot put glide technique. Three trials were allowed for each subject and the best of them was recorded. Furthermore, glide technique scores were calculated along with the distance. Technical scores were given out of 10 . The scores were given according to the grip of the shot, beginning stance, position, glide step, the position of the torso, throwing motion, the angle of the arm, applying the technical details that emerge from the throwing angle of the shot. While below 5 points were evaluated as technically inadequate, 5-6 was evaluated as average, 7-8 as good and 9-10 as very good. This scoring system was planned according to the parts and stages of the shot put technique and the degree of application of the combination of movements. The technical scores were given by the fourth rank track\&field national team coach of the shot put throw. The scoring was conducted in accordance with the technical details below.

\section{Procedure}

\section{Shot put throw glide technique:}

The initial phase: The athlete takes up his position with his back to the direction of the circle and weight of the body on the right leg. As the trunk is lowered the heel of the supporting leg is raised; the back leg is raised, slightly bent, to the rear and upwards and then immediately brought down again towards the other leg, both legs bending a good deal and trunk being lowered.

The Glide: the right leg is now immediately extended, giving drive from the sole and the heel of the rear foot while the left leg kicks back strongly towards the stop board; this joint action, which is preceded by an imbalance (sitting back) initiates the glide.

Final phase: This begins with turning the right foot and knee to the front at the same time as an extension of both legs; the hip is displaced laterally, the body weight is spread between the two legs. The left shoulder opens to the front and the right shoulder rises and rotates forward; the trunk takes up a somewhat arched position, due to the prior action of the lower torso.

The throw: Meanwhile the right shoulder and arm push the shot forward and the left shoulder continues to move forward for as long as possible (it does not move backward). The throw is completed on the left leg which extends fully as the hand gives the last impulse to the 
Artículo Original. The effect of life kinetic training on learning of shot put glide technique and motoric parameters. Vol. 7, n. ${ }^{\circ}$ 3; p. 363-385, septiembre 2021. https://doi.org/10.17979/sportis.2021.7.3.7445

implement; there is then an immediate reverse in which a change of leg is affected, the left moving backward, the body weight is taken on the right leg and trunk dropping downwards.

The shot must be of solid iron, brass or any metal not softer than brass, or a shell of such metal filled with lead or other material. Shot put was performed with a female: 4-kg male: $7.26 \mathrm{~kg}$ implement, using the glide technique, and following strictly the international rules of the event. The inner diameter of the circle was determined as $2.135 \mathrm{~m}$ and the throwing angle was determined as $34.92^{\circ}$. Angle lines of throwing were drawn by considering this angle. The students must start from a stationary and balanced position inside the circle. They must not leave the circle until the implement has touched the ground, and then his first contact with the ground outside edge of the stop board, but not the top. The shot must be put from the shoulder with one hand only. I the preliminary stance, it must be held close to the chin, and the hand must never drop below that position throughout the throw (Derse \& Hansen, 2012). Scoring was conducted by considering these rules (Figure 1).

\section{LK training:}

The content of LK educational applications has been created in a way that makes the movements difficult or complicated without being memorized by the students. The students were informed that the training content of Lk will be constantly changed. After the students start practicing the movements and learning takes place, the exercises are made difficult or complicated before they reach the memorization stage.

Experts add new combinations of moves to each application. In order to make the application more fun and attractive, various auxiliary tools are used in these combinations such as balls, jump ropes, small pulleys, pieces of ribbon and colored cards. In the selection and implementation of the exercises, the exercises described in detail below (Table 1) were applied from easy to difficult and individual, paired and group movements. Arms, feet, different tools or commands were added to the movements, allowing them to experience different variations.

Verbal and visual coding was conducted in the exercises that were applied to advanced levels (Table 1). It was required from students to apply the exercises in accordance with the 
Artículo Original. The effect of life kinetic training on learning of shot put glide technique and motoric parameters. Vol. 7, n. ${ }^{\circ}$ 3; p. 363-385, septiembre 2021. https://doi.org/10.17979/sportis.2021.7.3.7445

given commands. In the advanced level, both of the verbal and visual commands were given at the same time, however, students were required to apply only one of them and to create confusion (Lutz, 2010, 2014, 2017). The 12-week program was planned and applied with an expert who has an LK training certificate.

\section{Table 1: Life Kinetic Training Drills}

\begin{tabular}{|c|c|}
\hline 1 & $\begin{array}{l}\text { Throwing and holding a ball with two } \\
\text { hands while standing still. }\end{array}$ \\
\hline 2 & $\begin{array}{l}\text { Throwing and holding a ball with two } \\
\text { hands while walking forward, backward, } \\
\text { towards the right and left. }\end{array}$ \\
\hline 3 & $\begin{array}{l}\text { Throwing and holding a ball with two } \\
\text { hands while walking forward, backward, } \\
\text { towards right and left/ Throwing and holding a } \\
\text { ball with two hands while being directed by } \\
\text { verbal command/ Throwing and holding a ball } \\
\text { with two hands while being directed by visual } \\
\text { command/ Throwing and holding a ball with } \\
\text { two hands while walking and being directed } \\
\text { by both verbal and visual command, but } \\
\text { applying only one of them. }\end{array}$ \\
\hline 4 & $\begin{array}{l}\text { Throwing and holding a ball with right } \\
\text { hand to a higher distance and to a lower } \\
\text { distance with left hand/ to a lower distance } \\
\text { with right hand and to a higher distance with } \\
\text { left hand while standing still/ Throwing and } \\
\text { holding a ball with two hands while being } \\
\text { directed by verbal commands/ Throwing and } \\
\text { holding a ball with two hands while being } \\
\text { directed by visual commands. }\end{array}$ \\
\hline
\end{tabular}




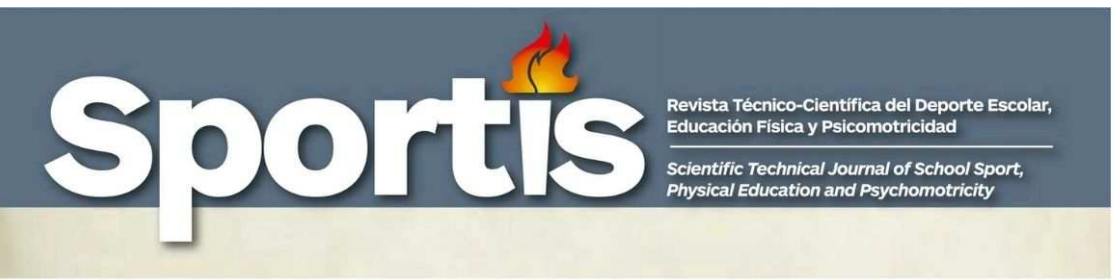

Artículo Original. The effect of life kinetic training on learning of shot put glide technique and motoric parameters. Vol. 7, n. ${ }^{\circ}$ 3; p. 363-385, septiembre 2021. https://doi.org/10.17979/sportis.2021.7.3.7445

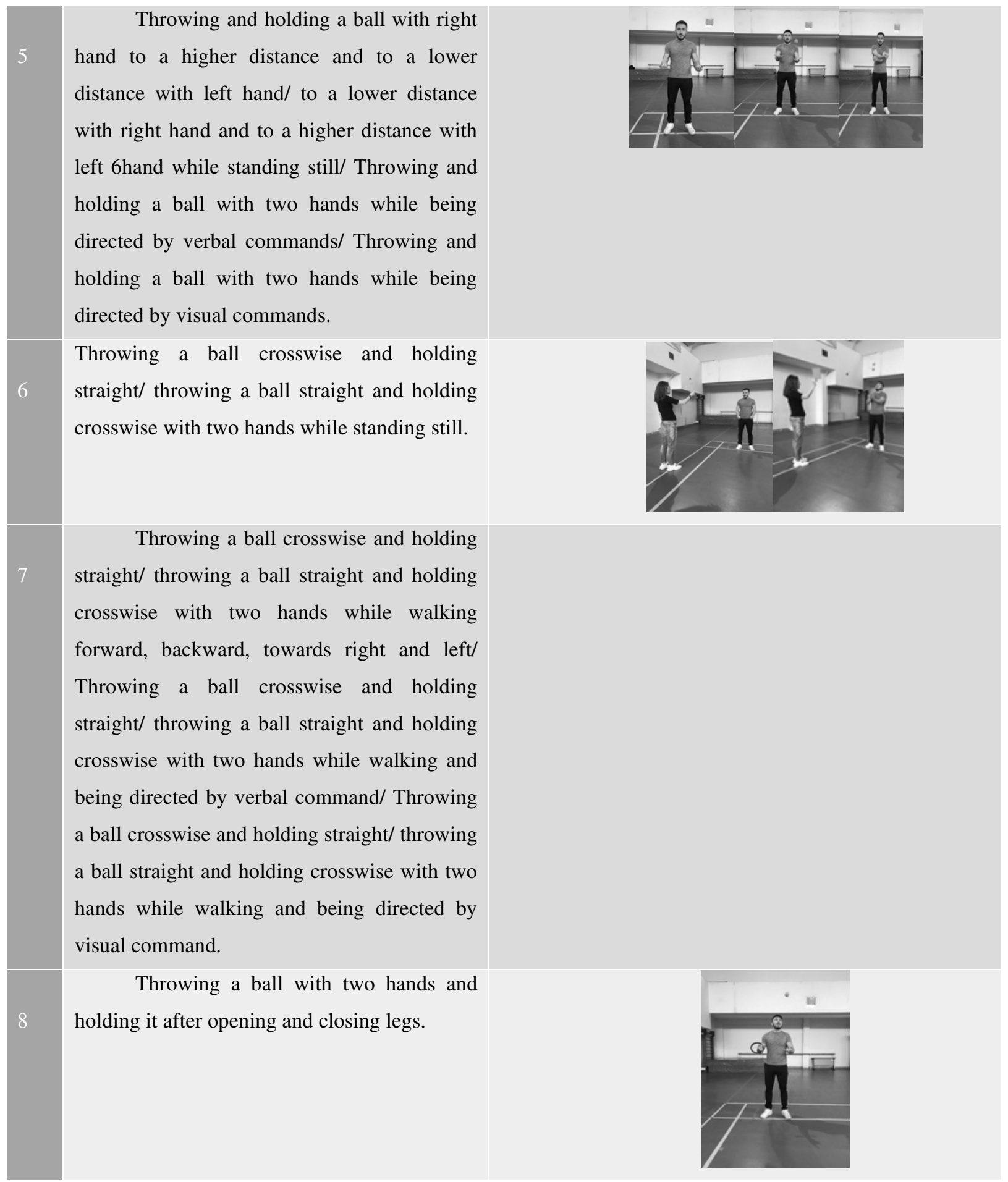




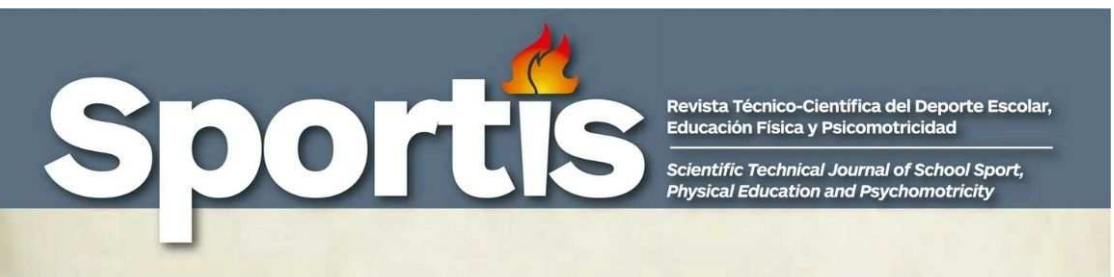

Artículo Original. The effect of life kinetic training on learning of shot put glide technique and motoric parameters. Vol. 7, n. ${ }^{\circ}$ 3; p. 363-385, septiembre 2021. https://doi.org/10.17979/sportis.2021.7.3.7445

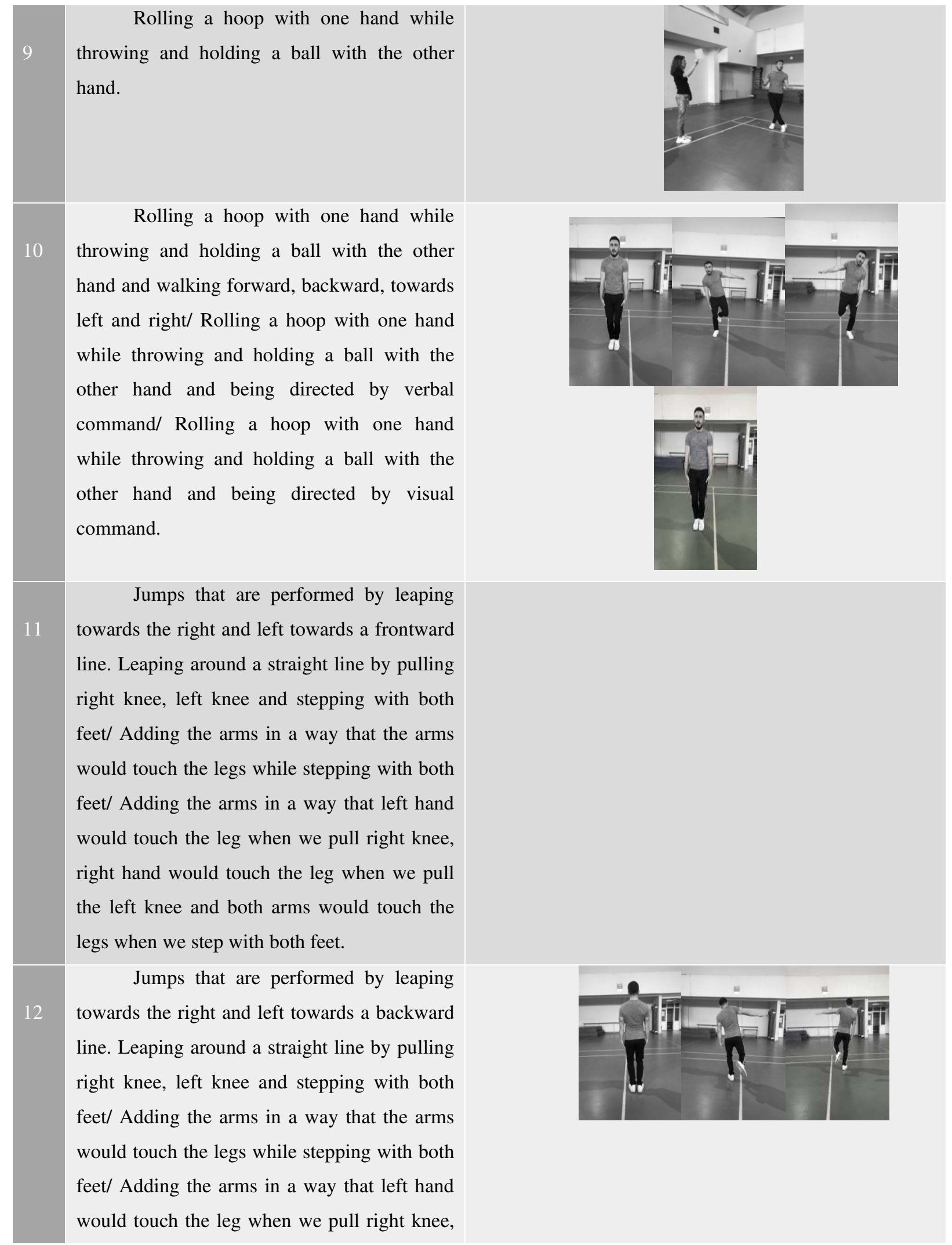


Artículo Original. The effect of life kinetic training on learning of shot put glide technique and motoric parameters. Vol. 7, n. ${ }^{\circ}$ 3; p. 363-385, septiembre 2021. https://doi.org/10.17979/sportis.2021.7.3.7445

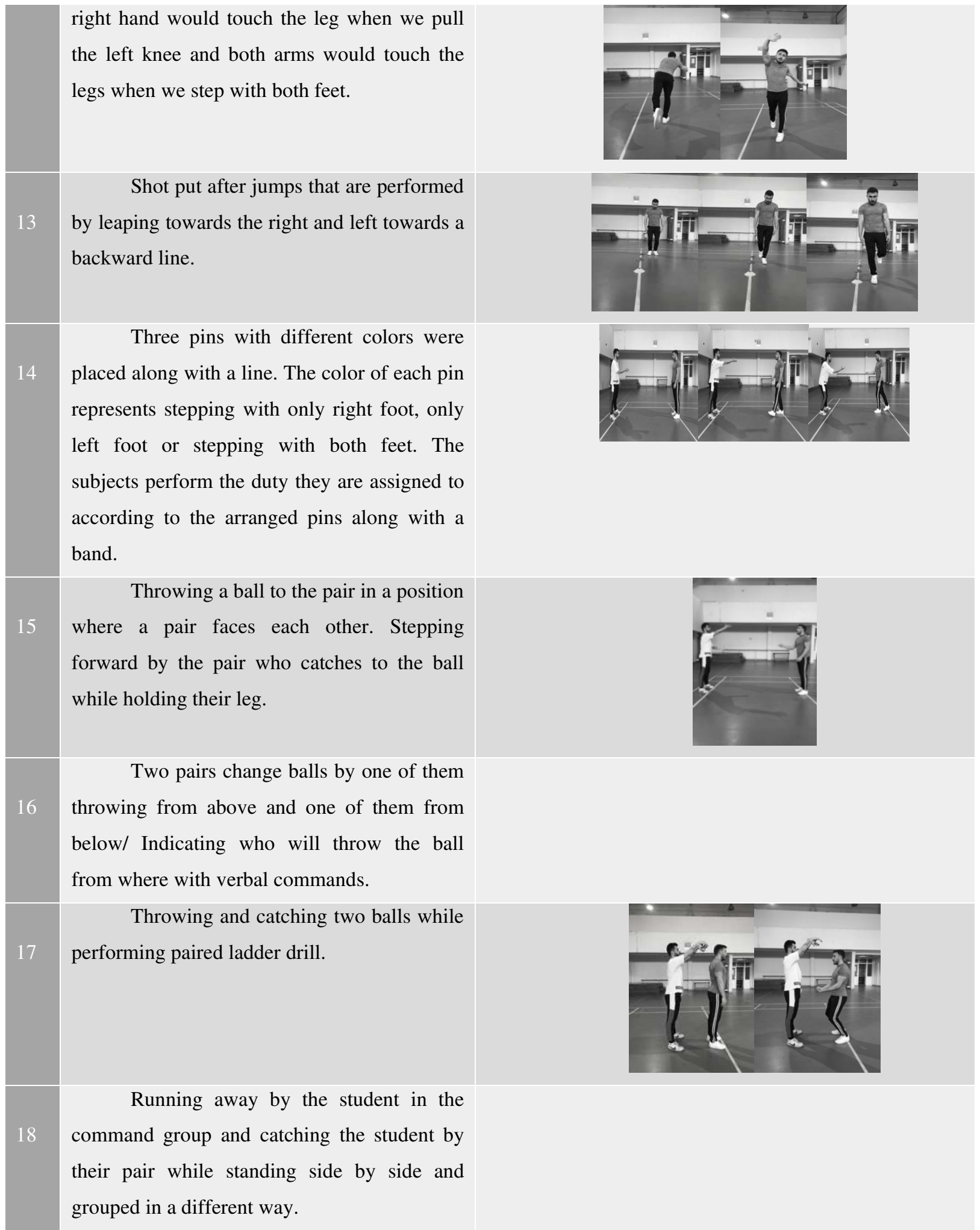


Artículo Original. The effect of life kinetic training on learning of shot put glide technique and motoric parameters. Vol. 7, n. ${ }^{\circ}$ 3; p. 363-385, septiembre 2021. https://doi.org/10.17979/sportis.2021.7.3.7445

While a pair waits facing back, the other student drops two balls from shoulder level with the command 'Now!' and the other student tries to catch the balls by turning around with both feet/ Coding the directions with colors and applying with a verbal command.

Rope, ball, hoop and ribbon tools are

placed all around the $10 \mathrm{~m}$ distance. However, one corner is ball corner (throwing and holding a ball with two hands), one corner is ribbon corner (spinning), one corner is rope corner (skipping rope with both feet) and the last corner is hoop corner (throwing and holding the hoop). Each corner is coded according to the colors. With the colored card, the student is asked to perform the duty in the required corner. The number of runs also determines the number of tasks ( 1 task for the first run, 2 tasks for the second run).

Skipping ropes start with skipping with one foot, both feet, bent leg, stretched leg/ Skipping forward, backward, sideways and cross/ Mixed variations

Skipping on a big rope that is spun by two students/ 5 students start to skip by standing successively. The first student in the front turns their back while continuing skipping, when the second student sees the face of the student in front they start to skip, when they face with the third student they start to skip and in this way, when all the 5 students turn the opposite direction, the skipping ends.
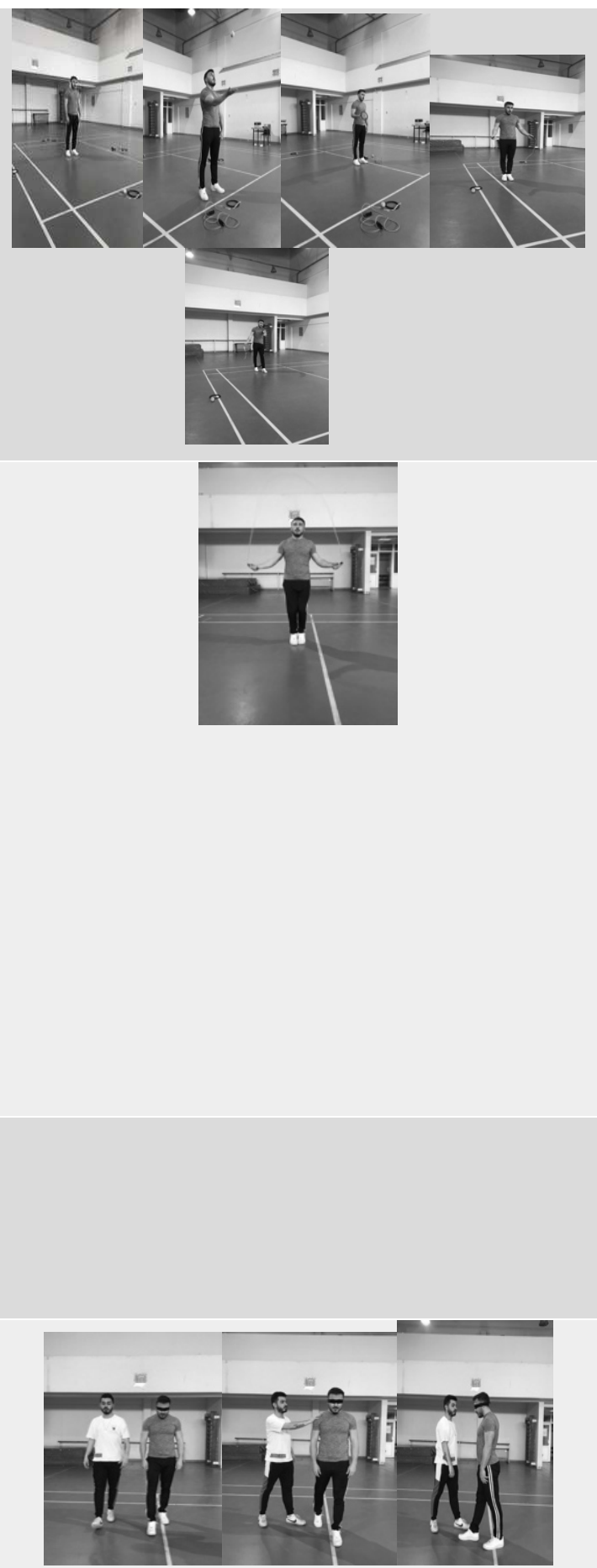
Artículo Original. The effect of life kinetic training on learning of shot put glide technique and motoric parameters. Vol. 7, n. ${ }^{\circ}$ 3; p. 363-385, septiembre 2021. https://doi.org/10.17979/sportis.2021.7.3.7445

Directing with the command: This
game which is played with two students, one
student is blindfolded after observing the
surrounding and starts to walk. The other
student tries to direct their pair by touching
their shoulder. The blindfolded student keeps
moving to the direction they were directed to
by turning 90 degrees. At the end of a
directing period of 1 minute, the blindfolded
stops and questions are asked to them about
the area. The student is expected to answer the
question "Where is the door?" correctly/ In a
game in which 3 out of 4 students are
blindfolded the directing student have to
prevent them from bumping into each other
and also provide them to stay in a certain area.

Statistical analysis: The analysis of the data was conducted in SPSS (Version 23.0; IBM SPSS Statistics; Armonk, NY) software. All continuous variables were expressed in terms of mean \pm standard deviation of the mean. If the Kolmogorov-Smirnov test showed most continuous variables were not normal, a nonparametric test was performed. The Wilcoxon test was performed to test the hypotheses about continuous data differences between the pre-test and post-test which were applied before and after the training program. The Mann Whitney $U$ test was used in order to determine whether or not there was a difference between the the experimental and control group in the shot put distance, glide technique, agility, visual reaction, auditory reaction parameters in two groups . Statistical significance level was taken as $\mathrm{p}<0.05$.

\section{Results}

At the end of the 12-week, it was determined that the experimental group demonstrated a better development (pre: 4.04 \pm 0.27 - post: $7.88 \pm 0.18$ ) than the control group (pre: 4.18 \pm 0.25 - post: $6.46 \pm 0.29)$ and a significant difference was observed $(\mathrm{p}<0.05)$. 
Artículo Original. The effect of life kinetic training on learning of shot put glide technique and motoric parameters. Vol. 7, n. ${ }^{0} 3$; p. 363-385, septiembre 2021. https://doi.org/10.17979/sportis.2021.7.3.7445

When the shot put distance values are compared between the experimental group (pre: $6.49 \pm 0.23$ - post: $7.42 \pm 02$ ) and control group (pre: $6.35 \pm 0.18$ - post: $6.82 \pm 0.22$ ) a significant development was observed $(\mathrm{p}<0.05)$.

In the velocity parameter, it was observed that experimental group (pre: $3.22 \pm 0.09-$ post: $3.06 \pm 0.07$ ) demonstrated a statistically significant development, control group $(3.19 \pm 0.09-3.11 \pm 0.06)$ could not develop sufficiently, however, there was no significant difference between groups.

In the agility parameter, while a statistically significant development was observed in the experimental group (pre: $17.9 \pm 0.25$ - post: $17.4 \pm 0.29$ ), there wasn't a difference in the control group (pre: $17.8 \pm 0.22$ - post: $17.6 \pm 0.19$ ). However, a significant difference between the groups was determined $(\mathrm{p}<0.05)$ Experimental group demonstrated a statistically significant development for the agility after the 12 weeks later compared to the control group.

In the visual reaction values, while a statistically significant difference was obtained in the experimental group (right hand pre: $251 \pm 7.4$ - post: $231.6 \pm 4.7$ / left hand pre: $233.8 \pm 9.2-$ post: $206.8 \pm 4.7)(p<0.05)$, it was observed that sufficient development was not obtained in the control group right hand pre: $249.9 \pm 9.4$ - post: $225.4 \pm 6.7$ / left hand pre: $225.9 \pm 6.2$ - post: $218.9 \pm 6.1$ ). When the difference between the groups was examined, a statistically significant difference between the experimental and control group was determined $(p<0.05)$. When the auditory reaction values were examined, a statistically significant result was observed in the left and right auditory reaction test of the experimental group right hand pre: $209.7 \pm 11.1-$ post:186 \pm 4.9 / left hand pre: $201.8 \pm 9.7$ - post: 179.6 \pm 9.2$)(\mathrm{p}<0.05)$. In the intergroup evaluation, while there was no difference in the right auditory reaction, a statistically significant development was observed in the experimental group (left hand pre: $201.8 \pm 9.7-$ post: $179.6 \pm 9.2$ ) than the control group (pre: $200.9 \pm 11.4$ - post: $183.4 \pm 10.7$ ).

Table 2. The Comparison of Descriptive Values

\begin{tabular}{|l|l|c|c|c|c|}
\hline \multirow{2}{*}{ Parameters } & \multicolumn{1}{|c|}{$\begin{array}{c}\text { Group } \\
\text { LK }(\mathrm{n}=26) \\
\text { Control }(\mathrm{n}=28)\end{array}$} & Pre-test & Post-test & $\begin{array}{c}\text { Within } \\
\text { Groups }\end{array}$ & $\begin{array}{c}\text { Between } \\
\text { Groups }\end{array}$ \\
\cline { 3 - 5 } & Mean \pm SD & Mean \pm SD & $\boldsymbol{p}$ & $\boldsymbol{p}$ \\
\hline \multirow{2}{*}{ Body Height $(\mathrm{cm})$} & LK & $174.4 \pm 2.29$ & $174.4 \pm 2.23$ & 0.80 & \multirow{2}{*}{0.31} \\
\cline { 2 - 5 } & Control & $172.3 \pm 1.83$ & $172.1 \pm 1.85$ & 0.20 & 0.82 \\
\hline Body Weight $(\mathrm{kg})$ & LK & $67.6 \pm 2.94$ & $67.3 \pm 2.79$ & 0.79 & 0.89 \\
\hline
\end{tabular}


Artículo Original. The effect of life kinetic training on learning of shot put glide technique and motoric parameters. Vol. 7, n. ${ }^{\text {3 }}$; p. 363-385, septiembre 2021. https://doi.org/10.17979/sportis.2021.7.3.7445

\begin{tabular}{|c|l|c|c|c|c|}
\hline & Control & $65.3 \pm 2.05$ & $65.2 \pm 2.01$ & 0.80 & \\
\hline \multirow{2}{*}{ BMI $\left(\mathrm{kg} / \mathrm{m}^{2}\right)$} & LK & $21.8 \pm 0.5$ & $21.9 \pm 0.5$ & 0.45 & 0.89 \\
\cline { 2 - 6 } & Control & $21.7 \pm 0.35$ & $21.8 \pm 0.35$ & 0.35 & 0.52 \\
\hline \multirow{2}{*}{ Body Fat $(\%)$} & LK & $14.4 \pm 1.01$ & $13.7 \pm 1.01$ & 0.28 & 0.74 \\
\cline { 2 - 6 } & Control & $12.5 \pm 1.05$ & $11.8 \pm 0.89$ & 0.54 \\
\hline
\end{tabular}

Table 3. The Comparison of Speed, Agility, Shot Put Performance and Glide Technique Points

\begin{tabular}{|c|c|c|c|c|c|}
\hline \multirow[t]{2}{*}{ Parameters } & $\begin{array}{c}\text { Group } \\
\text { LK }(n=26)\end{array}$ & Pre-test & Post-test & $\begin{array}{l}\text { Within } \\
\text { Groups }\end{array}$ & $\begin{array}{c}\text { Between } \\
\text { Groups }\end{array}$ \\
\hline & Control $(n=28)$ & Mean \pm SD & $\operatorname{Mean} \pm$ SD & $p$ & $p$ \\
\hline \multirow{2}{*}{ Speed (sn) } & LK & $3.22 \pm 0.09$ & $3.06 \pm 0.07$ & $0.01 *$ & \multirow{2}{*}{0.25} \\
\hline & Control & $3.19 \pm 0.09$ & $3.11 \pm 0.06$ & 0.49 & \\
\hline \multirow{2}{*}{ Agility (sn) } & LK & $17.9 \pm 0.25$ & $17.4 \pm 0.29$ & $0.00 *$ & \multirow{2}{*}{$0.04 *$} \\
\hline & Control & $17.8 \pm 0.22$ & $17.6 \pm 0.19$ & 0.72 & \\
\hline \multirow{2}{*}{$\begin{array}{l}\text { Shot Put performance } \\
(\mathrm{cm})\end{array}$} & LK & $6.49 \pm 0.23$ & $7.42 \pm 0.2$ & $0.00 *$ & \multirow{2}{*}{$0.01 *$} \\
\hline & Control & $6.35 \pm 0.18$ & $6.82 \pm 0.22$ & $0.00 *$ & \\
\hline \multirow{2}{*}{$\begin{array}{lr}\text { Shot Put } & \text { Glide } \\
\text { Technique } & \text { Values } \\
\text { (point) } & \end{array}$} & LK & $4.04 \pm 0.27$ & $7.88 \pm 0.18$ & $0.00 *$ & \multirow[b]{2}{*}{$0.00 *$} \\
\hline & Control & $4.18 \pm 0.25$ & $6.46 \pm 0.29$ & $0.00 *$ & \\
\hline
\end{tabular}

Table 4. The Comparison of Visual Reaction and Auditory Reaction Values

\begin{tabular}{|c|c|c|c|c|c|}
\hline \multirow[t]{2}{*}{ Reaction Parameters } & \multirow{2}{*}{$\begin{array}{c}\text { Group } \\
\text { LK }(\mathrm{n}=26) \\
\text { Control }(\mathrm{n}=28)\end{array}$} & Pre-test & Post-test & $\begin{array}{l}\text { Within } \\
\text { Groups }\end{array}$ & $\begin{array}{c}\text { Between } \\
\text { Groups }\end{array}$ \\
\hline & & Mean \pm SD & Mean \pm SD & $p$ & $p$ \\
\hline \multirow{2}{*}{ Right Visual (ms) } & LK & $251.2 \pm 7.4$ & $231.6 \pm 4.7$ & $0.00 *$ & \multirow{2}{*}{$0.04 *$} \\
\hline & Control & $249.9 \pm 9.4$ & $225.4 \pm 6.7$ & 0.07 & \\
\hline \multirow{2}{*}{ Left Visual (ms) } & LK & $233.8 \pm 9.2$ & $206.8 \pm 4.7$ & $0.01 *$ & \multirow{2}{*}{$0.03 *$} \\
\hline & Control & $225.9 \pm 6.2$ & $218.9 \pm 6.1$ & 0.33 & \\
\hline \multirow{2}{*}{ Right Auditory (ms) } & LK & $209.7 \pm 11.1$ & $186 \pm 4.9$ & $0.03 *$ & \multirow[t]{2}{*}{0.58} \\
\hline & Control & $204.8 \pm 8.6$ & $192.5 \pm 7.2$ & 0.24 & \\
\hline
\end{tabular}


Artículo Original. The effect of life kinetic training on learning of shot put glide technique and motoric parameters. Vol. 7, n. ${ }^{\circ}$ 3; p. 363-385, septiembre 2021. https://doi.org/10.17979/sportis.2021.7.3.7445

\begin{tabular}{|c|l|c|c|c|c|}
\hline Left Auditory (ms) & LK & $201.8 \pm 9.7$ & $179.6 \pm 9.2$ & $0.00^{*}$ & $0.04 *$ \\
\cline { 2 - 5 } & Control & $200.9 \pm 11.4$ & $183.4 \pm 10.7$ & 0.07 & \\
\hline
\end{tabular}

\section{Discussion}

The effect of LK training which was done in conjunction with the track\&field lessons by the university students who participated in the research on the glide technique and motor parameters was examined. As a result of the research, a statistically significant difference was determined between the experimental and control group in the parameters of velocity, shot put distance, glide technique, agility, right and left visual reaction and left auditory reaction.

According to the results that were obtained from the research, the statistically significant differences between the experimental and control group in terms of the shot put distance and glide technique can be interpreted in a way that LK exercises can improve the technical capacity. Considering the fact that the technique is affected by several factors such as cognitive intelligence, learning capacity, motor skills, it can be assumed that LK training which comprises of physical and mental tasks that are given in a complicated and extensive way may develop the technique in addition to provide development on several aspects (Lutz, 2017).

When the literature was reviewed, it was noted that the effects of LK training focused on balance, eye-foot, eye-hand coordination, attention and perception factors. (Grünke, 2011). In the literature LK training provides an increase in mental capacity in athletes and encourages the formation of special and combined movement abilities (Duda, 2015). This process can affect the learning speed of the movements and the stage of technical learning in individuals (Lees, 2002). In a research on football players LK shapes mental capacity it seems that one can greatly accelerate the process of learning a game. This position was confirmed in a significant way for learning football, where creative training and in the application of complex methods (activation of the mental sphere) and in the decision-making practice, enhanced efficiency was achieved (Duda, 2015). In another studies examining the effects of first training on learning brain neuromuscular training in children has been examined in their 
Artículo Original. The effect of life kinetic training on learning of shot put glide technique and motoric parameters. Vol. 7, n. ${ }^{\circ}$ 3; p. 363-385, septiembre 2021. https://doi.org/10.17979/sportis.2021.7.3.7445

research on basic movement skills and physical self-efficacy, and it has been determined that a 10-week neuromuscular training program provides a dimension in the quality of basic movement skills in the 6-7 age group (Duncan, Eyre, \& Oxford, 2018; Haas, 2002; Fernandez et.al., 2018).

Athletes need technical learning action in almost every workout. (Stone et al., 2003). Even though they are on different levels, the majority of the athletes' training programs are planned on the development of technical competence (Kyriazis, Terzis, Boudolos \& Georgiadis, 2009). In branches where there is a relationship between technical competence and performance such as track\&field, both the learning process and the content should be planned well (Stone et al., 2003). When the researchers examined LK training and technical learning processes, it was found that it was found in 3-12 weeks. In the research, the experiment period was applied as 12 weeks in order to learn the shot put technique and understand the effect of LK training better. In another study on shot put technique and teaching, it was revealed that an improvement of 5\% was observed in a period of 8 weeks (Kyriazis, Terzis, Karampatsos, Kavouras \& Georgiadis, 2010).

While the research was planned, it was applied as 12 weeks in order to see the effects of both the learning process of the shot put technique and the LK training. In the study, it was determined that there were statistically significant improvements in both technical scoring and shooting distance at the end of 12 weeks in the students who applied LK training. Conducted researches indicate that neuromuscular training positively affects cognitive and motor development (Kyriazis, Terzis, Karampatsos, Kavouras \& Georgiadis, 2010; Pietsch, Böttcher \& Jansen, 2017). One of the most important criteria for technical capacity development is the development of the level of motor skills. Sufficient strength, velocity, reaction or agility skills are important in terms of reflecting the technical capacity to the field. Each physical activity style consists of a combination of different motor skills.

In this research, when the motor skill levels of students were examined after the 12week training period, it was observed that the experimental group demonstrated a significant development in the velocity parameter and control group could not develop sufficiently, however there wasn't a significant difference between the groups and while the experimental 
Artículo Original. The effect of life kinetic training on learning of shot put glide technique and motoric parameters. Vol. 7, n. ${ }^{\circ}$ 3; p. 363-385, septiembre 2021. https://doi.org/10.17979/sportis.2021.7.3.7445

group demonstrated a significant development in the agility parameter, there wasn't any difference in the control group. However, a significant difference was determined between the groups $(p<0.05)$. In the reaction values, while a statistically significant difference was obtained in the visual reaction of the experimental group $(p<0.05)$, it was observed that sufficient development could not be provided in control group. When the intergroup difference is evaluated, a statistically significant difference was determined between the experimental and control group $(p<0.05)$. When the auditory reaction is evaluated, a statistically significant difference was observed in the right and left auditory reaction test of the experimental group $(p<0.05)$. In the intergroup evaluation, while there wasn't a difference in the right auditory reaction, it was determined that the experimental group demonstrated a more significant development than the control group in the left auditory reaction. In the literature, studies examining the motor skills of LC training and different areas have been examined in recent years. Life Kinetic training has a significant effect on increasing concentration, motivation, and learning outcomes in tennis skills (Komarudin, 2016). Life Kinetic training had a significant influence on critical thinking skills, anticipation, and performance of martial arts athletes (Mulyana, 2016). In conclusion, it can be explain that LK training is far more effective in the agility and reaction parameters. LK training can be effective in establishing new neural connections or developing the existent connections in the neural system by providing athletes to focus on visual and physical tasks at the same time (Lutz, 2017). It is expected from the exercises which are constantly challenging and supported with new forms such as LK training to have a positive effect on the complex movement combinations in the exercises (Pietsch, Böttcher \& Jansen, 2017). In addition to this, it is mentioned that the LK training system has effects such as shortening the learning process and facilitating the learning. Researches in the literature indicate that the LK training provides developments in the cautiousness and reaction time, learning, perceiving, and giving quick reactions of the athletes (Hannes, 2009; Vural, 2016).

In conclusion, as a result of the training and technical education programs applied to both groups, the all students made progress on each parameter. However it was determined that the LK training applied in this research provided development in the technical performances and motor skill levels of students. A significant development was observed 
Artículo Original. The effect of life kinetic training on learning of shot put glide technique and motoric parameters. Vol. 7, n. ${ }^{\circ} 3$; p. 363-385, septiembre 2021. https://doi.org/10.17979/sportis.2021.7.3.7445

especially in the reaction and agility parameters. It is considered that LK training is a comprehensive training which may affect the technical capacity and the development of basic motor skills and these researches would affect the technical training and motor skills of individuals who are beginner athletes.

\section{Referencias bibliográficas}

Adrian, L. (2002). Technique analysis in sports: a critical review. Journal of Sports Sciences, 20:10, 813-828. https://doi.org/10.1080/026404102320675657

Amiri-Khorasani, M., Sahebozamani, M., Tabrizi, K.G., \& Yusof, A.B. (2010). Acute effect of different stretching methods on illinois agility test in soccer players. J Strength Cond Res, 24: 2698-2704, https://doi:10.1519/JSC.0b013e3181bf049c

Caleb, D. Bazyler, S.M., Alex, P., Harrıson, S.K., Kavanaugh A.A., Deweese, B.H., \& Stone, M.H. (2017). Changes in muscle architecture, explosive ability, and track and field throwing performance throughout a competitive season and after a taper. J Strength Cond Res , 31(10)/2785-2793, https://doi:10.1519/JSC.0000000000001619

Castel, A.D., Pratt, J., \& Drummond, E. (2005). The effects of action video game experience on the time course of inhibition of return and the efficiency of visual search. Acta Psychologica, 119: 217-230, https://doi:10.1016/j.actpsy.2005.02.004

Derse, E., \& Hansen, J. (2012). Track and Field Coaching Manual, USA, LA84 Foundation, 400-420.

Duda, H. (2015). Application of life kinetik in the process of teaching technical activities to young football players. Antropomotoryka. Journal of Kinesiology and Exercise Sciences, 71(25):51-61, 2015, https://doi:10.5604/17310652.1203803

Duncan, M.J., Eyre, E.L.J., \& Oxford, S.W. (2018). The effects of 10-week integrated neuromuscular training on fundamental movement skills and physical self-efficacy in 6-7 year old-children.,J.Strength.Cond.Res,32(12):3348-3356, https://doi:10.1519/JSC.0000000000001859

Faigenbaum, A.D., Farrell, A., Fabiano, M., Radler, T., Naclerio, F., Ratamess, N.A., Kang, J., \& Myer, G.D. (2013). Effects of integrative neuromuscular training on fitness 
Artículo Original. The effect of life kinetic training on learning of shot put glide technique and motoric parameters. Vol. 7, n. ${ }^{\circ} 3$; p. 363-385, septiembre 2021. https://doi.org/10.17979/sportis.2021.7.3.7445

performance in children. Pediatr Exerc Sci, 23: 573-584, https://doi:10.1123/pes.23.4.573

Fernandez, D.A.G., Valenzuela, M.E.C., Chavez, C.C., Delgado, J.C.G., Saucedo, G.V.\& Gonzalez, M.Z.M. (2018). Impact of a motor activity program with executive functions to strengthen the integral development of the child, Scieentific Technical Journal of School Sport, Physical Education and Psychomotricity, Vol.4, No.1, 37-58, https://doi:10.17979/sportis.2018.4.1.2060

Goriely, A., \& Kuhl, E. (2015). Neuromechanics: from neurons to brain. Advances in Applied Mechanics, vol. 48, p. 79-139, https://doi:10.1016/bs.aams.2015.10.002

Grünke M. (2011): Die Effekte des Life Kinetik-Trainings auf die Aufmerksamkeits- und die Fluide Intelligenzleistung von Kindern mit gravierenden Lernproblemen, Heilpädagogische Forschung, Band 37, Heft 1.

Haas C.S., \& Scholz M. (2011): Qualitative Untersuchung des Einflusses von Life Kinetik auf die kognitive Leistungsfähigkeit bei Grundschülern, PhilosophischSozialwissenschaftliche Fakultät der Universität Augsburg, Institut für Sportwissenschaft (unveröffentlicht).

Hannes, D., \& Evaluation des L.K. (2009). Konzeptes an einer Förderschule mit dem Förderschwerpunkt Lernen. Universität zu Köln Humanwissenschaftliche Fakultät Department Heilpädagogik und Rehabilitation, 84-90.

Jain, A., Bansal, R., Kumar, A., \& Singh, K.D. (2015). A comparative study of visual and auditory reaction times on the basis of gender and physical activity levels of medical first year students. Int J Appl Basic Med Res, 5: 124-127, https://doi:10.4103\%2F2229$\underline{516 X .157168}$

Komarudin, K., \& Awwaludin, N.P. (2018). Life kinetik training in improving the physical condition of football athletes. 3rd International Conference on Sport Science, Health, and Physical Education, Advances in Health Sciences Research, volume 11.

Kyriazis, T., Terzis G., Karampatsos, G., Kavouras, S., \& Georgiadis, G. (2010). Body composition and performance in shot put athletes at preseason and at competition. International Journal of Sports Physiology and Performance, 5(3):417-421, https://doi:10.1123/ijspp.5.3.417 
Artículo Original. The effect of life kinetic training on learning of shot put glide technique and motoric parameters. Vol. 7, n. ${ }^{\circ}$ 3; p. 363-385, septiembre 2021. https://doi.org/10.17979/sportis.2021.7.3.7445

Kyriazis, T.A., Terzis, G., Boudolos, K., \& Georgiadis, G. (2009). Muscular power, neuromuscular activation, and performance in shot put athletes at preseason and at competition period. Journal of Strength and Conditioning Research, 23: 1773-1779, https://doi:10.1519/JSC.0b013e3181b3f91e

Lees, A. (2002). Technique analysis in sports: a critical review, Journal of Sports Sciences, 2010, 813-828, https://doi:10.1080/026404102320675657

Linthorne, N.P. (2001). Optimum release angle in the shot put. Journal of Sports Sciences, 19: 359-37, https://doi:10.1080/02640410152006135

Lutz, H. (2010). Fußball spielen mit LK. Münih, Blv buchverlag gmbh co 1:143.

Lutz, H. (2014). Untersuchungs-Ergebnisse Praventionskurs"Entspannung = weniger Stress". Unveröffentlichte Fallstudie, Life Kinetik Seminarzentrum, 13-26.

Lutz, H. (2017). Life Kinetik Bewegung macht Hirn. Meyer\&Meyer Verlag, München, 2127,45-52.

Meron, A., \& Saint-Phard, D. (2017). Track and field throwing sports: injuries and prevention. Current Sports Medicine Reports: 11/12 2017 - Volume 16 - Issue 6 - p 391396, https://doi:10.1249/JSR.0000000000000416

Mike A.W., Matthew J., Gersick, M.S., Robert J., Townsend, M.S., Candus N., \& Ford, B.S. (2014). Strength and conditioning preparation for the transitional track and field thrower, Strength and Conditioning Journal, 36 (6), https://doi:10.1519/SSC.0000000000000102

Pietsch, S., Böttcher, C., \& Jansen, P. (2017). Cognitive motor coordination training improves mental rotation performance in primary school - aged children. Mind, Brain and Education, 11:4, https://doi:10.1111/mbe.12154

Stern,Y. (2002). What is cognitive reserve? Theory and research application of the reserve concept. Journal of the International Neuropsyhological Society, 8, 448-460, https://doi:10.1017/S1355617702813248

Stone, M.H., O’Bryant, H.S., Mccoy, L., Coglianese, R., Lehmkuhl, M., \& Shilling, B. (2003). Power and maximum strength relationships during performance of dynamic and static weighted jumps. J Strength Cond Res, 17: 140-147, https://doi:10.1519/15334287(2003)017\%3C0140:pamsrd\%3E2.0.co;2 
Artículo Original. The effect of life kinetic training on learning of shot put glide technique and motoric parameters. Vol. 7, n. ${ }^{\circ}$ 3; p. 363-385, septiembre 2021. https://doi.org/10.17979/sportis.2021.7.3.7445

Vural, M.U. (2016). Life Kinetik antrenmanlarının genç basketbolcularda denge, reaksiyon süresi ve dikkat üzerine etkisi. Gazi Üniversitesi Sağlık Bilimleri Enstitüsü, Yüksek Lisans Tezi, 39-43.

Yarım, İ., Çetin, E., \& Orhan, Ö. (2019). Effects of life kinetics on performance athletes. Journal of Sport Sciences Researches, 4:2, https://doi:10.25307/jssr.581943

Zaras, N., Spengos, K., Methenitis, S., Papadopoulos, C., Karampatsos, G., Georgiadis, G., Stasinaki, A., Manta, P., \& Terzis, G. (2013). Effects of strength vs. ballistic-power training on throwing performance, Journal of Sports Science and Medicine, 12, 130-137. PMCID: PMC3761775 